NikLaI Patrícia Dominika

PhD-hallgató

PTE ÁJK
DOI: 10.15170/DiKE.2019.03.01.08

\title{
A nyolcosztályos népiskolai oktatás bevezetésének hatása az iskolalátogatással kapcsolatos szülöi felügyeleti jogra
}

\section{The Effect of Introducing the 8-Grade Elementary Schooling on Parents' Supervisory Rights regarding School Attendance}

In connection with the implementation of the eight-grade elementary school system, questions were raised about the necessity of the work of children in the family and the need for compulsory education and the right of the child to education. The introduction of the eight-grade elementary school system was an important matter under the ministry of Kuno Klebelsberg, however, it was realized by Bálint Hóman, as a result of the Act XX of 1940 on schooling obligation and eight-grade elementary school. During the preparation of the Act, in 1939 Kálmán Kósa, the head of class of the ministry highlighted, that it is important to increase the duration of compulsory schooling, however, it should be kept in mind, that 'the adolescent children can continue to participate in the agricultural work, help their family with their work, when it is inevitably necessary to provide daily bread.' Since the burden of parents would increase in the case of introducing eight-grade schooling, he urged to introduce two, a lower and a higher section in elementary school, so the students of the higher section would not go to school between April and October in order to belp at home. The so called 'Néptanitók. Lapja' (Teacher's Journal) published the Act and its ministerial reasoning in 1940. Minister Homan called it the most serious disability of the educational system that the majority of our students finish their studies at their 12th age, which is the time, when they come to a dangerous and transient period of physical and psychological development.' In my essay I will examine these two questions, highlighted by the Ministry of Culture as well, regarding the parents' supervisory rights. On the one hand it is necessary to introduce eight-grade elementary schooling to educate children over the age of 12 properly, and on the other hand it is also important to limit the time of the eight-grade system, to ensure that the children can help at home. In order to find answers to these questions I will examine the provisions of the act, its ministerial reasoning and its welcome in the pedagogical press, and practical problems which led to the creation of the Act based on the documents of the National Archives of Hungary Baranya County Archives - such as the case of the thief band of the students of Pécs, as well as the reaction of the city to this band and the manifestation of the extraordinary effect of parental care. As it was written in many writings, it is also my aim to emphasize, that children's behavior in this age was - and is nowadays - mostly effected by the family, so the success of introducing eight-grade schooling depends firstly on the relationship between the child and the parent, secondly on the relationship between the family and the school.

Keywords: family and school, compulsory schooling, eight grade elementary school system 


\section{Bevezető}

„Alulirott azon tiszteletteljes kérelmemmel járulok. Nagyságos Királyi Tanfelügyelo" Úr kegyes szine elé, hogy a kórósi ref. népiskola VII-ike osztályába járó fiamat: iff. Balog Mikó Józsefet a tanév bátra lévó idejére az. iskolábajárás kötelezettsége alól felmenteni kegyeskedjék. Kérésem támogatására felhozom: az idô elöre haladott voltát, a rossz idójárás miatt a munkákban való hátramaradottságunkat. Községünkben napszámost vagy egyéb segédmunkaeröt kapni nem lehet, igy fiam segitségére égetö nagy sұülkségem van kis gazdaságomban, mert csak. igy leszek képes hazafias kötelességemnek is eleget tenni - a termelés tekintetében."

A nyolcosztályos elemi iskolai rendszer megvalósítása során mint tisztázandó kérdés merült fel a gyermekek által a családi gazdaságban végzett munka szükségessége és a gyermek iskoláztatáshoz való joga közötti kapcsolat. A 20. század közepén egyrészt szükség volt a tankötelezettség biztosítására, hogy ezáltal a gyermek iskoláztatáshoz való joga érvényre juthasson, ennek pedig fontos része volt a nyolcosztályos népoktatás bevezetése a 12 év alatti gyermekek megfelelő oktatása és nevelése érdekében. Másrészt az 1940-es években, amikor a nyolcosztályos rendszert bevezették, magas volt az igény a gyermekek munkájára a családi gazdaságban, ezért a tankötelesség kialakítása során figyelemmel kellett lenni erre a szempontra is és korlátozni kellett a népoktatásban való részvétel időtartamát a szorgalmi idő tekintetében.

Jelen tanulmányban e szempontok alapján tárom fel a nyolcosztályos népiskolai oktatás 1940-ben történt bevezetésének a szülők felügyeleti jogait érintő hatását. A kérdések vizsgálatához áttekintem a témára vonatkozó 1940. évi XX. törvénycikk rendelkezéseit, annak miniszteri indokolását és fogadtatását a pedagógiai lapokon keresztül. A jogszabályi környezet érvényesülésének, illetve a hétköznapokban kifejtett hatásának feltárásához a Magyar Nemzeti Levéltár Baranya Megyei Levéltárának tanfelügyelőségi iratait veszem alapul, ezen belül a pécsi tanköteles gyermekekből álló tolvajbanda esete, a város erre adott reakciója, valamint a szülói gondozás rendkívüli hatásának megnyilvánulása nyomán ismertetem a gyakorlati problémákat, amelyek a törvény megalkotásához vezethettek.

\section{Az iskolai kötelezettségről és a nyolcosztályos népiskoláról szóló 1940. évi XX. törvénycikk megalkotása és fogadtatása}

A nyolcosztályos közoktatási rendszer bevezetése már Klebelsberg Kuno minisztersége $e^{2}$ alatt felmerült, majd az 1930-as években is többen felvetették a szükségességét, de ekkor még a gazdasági világválság következtében előállt anyagi nehézségekre hivatkozva nem valósították meg. ${ }^{3} \mathrm{~A}$ jogszabályi alapot végül Hóman Bálint kultuszminiszter ${ }^{4}$ teremtette meg az iskolai kötelezettségről és a nyolcosztályos népiskoláról szóló 1940. évi XX. törvénycikkel.

A törvény előkészítése során, 1939-ben jelent meg Kósa Kálmán miniszteri osztályfőnök „A nyolcosztályos népiskola és az egyházake” címú írása a Néptanítók Lapjában. Kiemelte, hogy fontos a gyermekek taníttatása időtartamának növelése - mind a napi iskolában töltött időtartam, mind az évek tekintetében -, ugyanakkor szem előtt kell tartani, hogy „, a serdülo" gyermek továbbra is részt vehessen a termelö munkában, munkaerejével segitségére lehessen családjának akekor, amikor ąt a mindennapi kenyér

\footnotetext{
${ }^{1}$ MNL BaML VI. 502. Bvm. és Pécs v. Tanfelügyelőségének iratai 1695/1942.

2 Klebelsberg Kuno 1922. június 16. és 1931. augusztus 24. között volt kultuszminiszter.

${ }^{3}$ Lásd MANN, Oktatáspolitikusok és koncepciók a két világháború között 36-78.

${ }^{4}$ Hóman Bálint kétszer töltötte be a kultuszminiszteri pozíciót, először 1932. október 1. és 1938. május 13., másodszor 1939. február 16. és 1942. július 3. között.
} 
biztositása elkerülhetetlenül szü̈kéegessé teszi.” Hangsúlyozta, hogy anyagi okokból mindez nem valósítható meg azonnal és teljes egészében, így a fokozatos bevezetést vetítette előre, amely enyhítené a kiadásokat központi és helyi szinten is, tehát mind az államkincstár, mind az iskolafenntartó tekintetében. A szülők terhei is nőnének a nyolcosztályos oktatás bevezetésével, ezért is tartotta fontosnak a két (alsó és felső) tagozat bevezetését, ezáltal a felső tagozat diákjai április és október között nem járnának iskolába, hanem otthon segíthetnének, mivel a szorgalmi idő október 15-től április 15-ig tartana számukra. Ez véleménye szerint némi megoldást nyújtana arra, hogy egyrészt nem lenne szükség a tanerő és tanterem szükséglet azonnali növelésére, másrészt a szegényebb családok számára nem jelentene jelentős többletköltséget és a gyermekek munkaerejének kiesését, valamint „megszüntetné a szegényebb néprétegeknek az iskolával szemben abból kifolyólag táplált idegenkedését, hogy az iskoláztatást büntetésekekel is kikényszeritó rendelkezések sokszor éppen

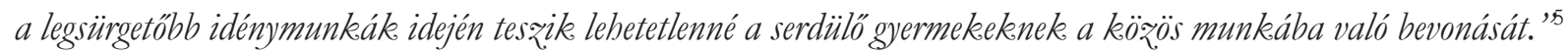

A nyolcosztályos népiskola megvalósítását Hóman Bálint vallás- és közoktatásügyi miniszter 1939. november 22-i költségvetési beszédében jelentette be, amelyről a Néptanítók Lapja 1939. decemberi száma emelkedett, ünnepélyes hangvételben számolt be. A magyar tanítóság régi vágyának megtestesüléseként jellemezték a nyolcosztályos népoktatás bevezetését. ${ }^{6}$
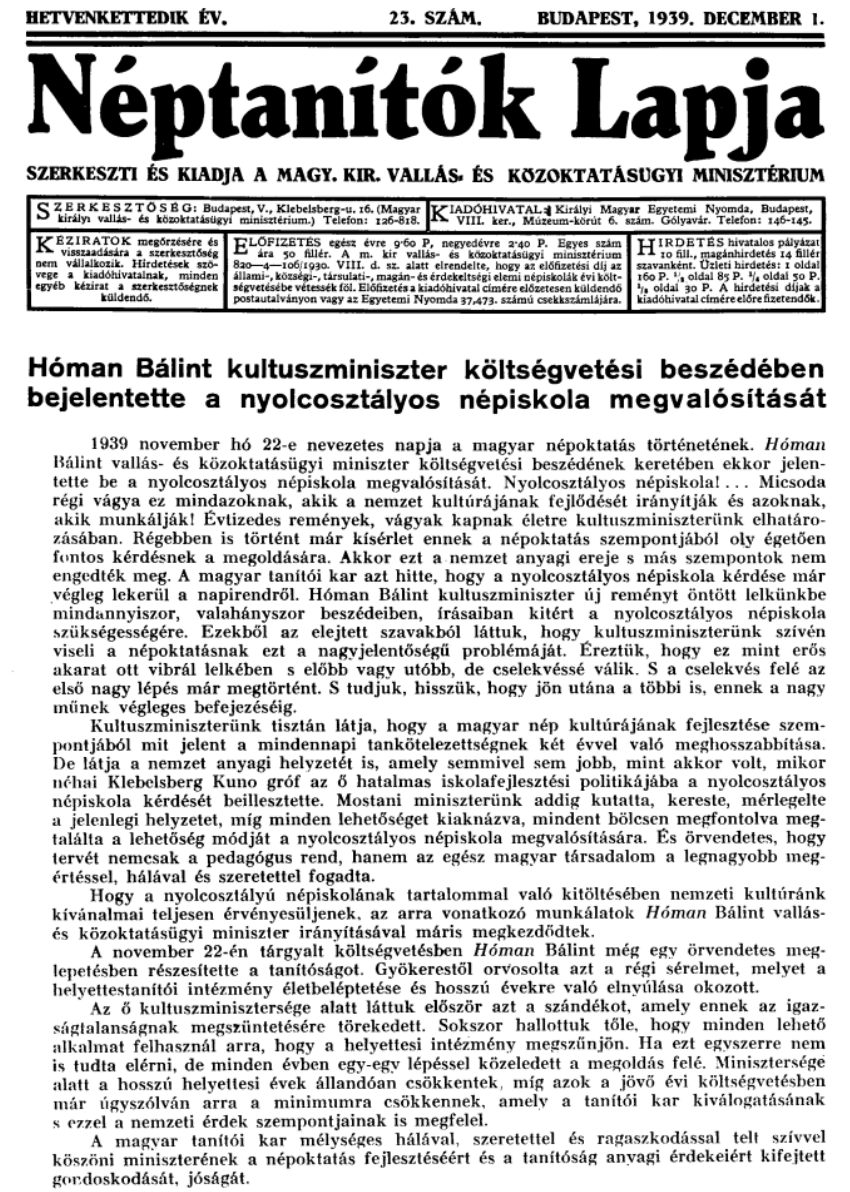

1. kép: Hóman Bálint kultuszminiszter költségvetési beszédében bejelentette a nyolcosztályos népiskola megvalósítását. Néptanítók Lapja 1939/23. sz.

(1939. december 1.)

\footnotetext{
${ }^{5}$ KósA, A nyolcosztályos népiskola és az egyházak 793-796.

${ }^{6}$ Bővebben lásd: Hóman Bálint kultuszminiszter költségvetési beszédében bejelentette a nyolcosztályos népiskola megvalósítását 913.
} 
Szintén a Néptanítók Lapja közölte a törvényjavaslatot és a miniszteri indokolást 1940. évi 10. számában. Hóman az indokolásban a népiskolai rendszer legsúlyosabb fogyatékosságának nevezte - a nevelés szempontjából -, hogy „népiskolai tanulóink túlnyomó többsége életének tiz̨enkettedik évével befejez̧i rendsz̨eres tanulmányait, tehát éppen akekor, amikor testi és lelki fejlödésében a serdillésnek minden tekintetben veszedelmes és átmeneti idöszakához ér”. Ennek a hibának kiküszöböléséhez szükségesnek tartotta a nyolcosztályos oktatás bevezetését, amely által a mindennapi népiskolai oktatás időtartamát növelnék, így a gyermeket tovább nevelhetnék, oktathatnák ilyen fogékony korban, mint a tizenkettőtől kezdődő évek. Az indokolásban az a koncepció jelent meg, amelyet Kósa Kálmán is előrevetített: a felső tagozat szorgalmi ideje 6 hónapig, októbertől áprilisig tart, így Hóman szerint a törvényjavaslat alkalmazkodik az élet gyakorlati követelményeihez, tehát a szülők számára nem jelent majd nagy nehézséget a gyermekek tovább tartó iskolai oktatása. A miniszter a következőképpen összegezte a szorgalmi idő beosztásának indokolását: „Olyan rendelkęzés, mely a szorgalmi idö tekintetében nem tesz. különbséget a tanköteles gyermekek. között és minden tí éven felüli serdültebb gyermeket válogatás nélkül tí, hónapon keresżül bekényszeritene az iskola padjaiba, nagyon komoly népi érdekeket sértene és egyuittal alkealmas lenne arra, hogy falusi és tanyai népünk az iskolában a megélhetésért folytatott amúgy is súlyos kürqdelmének megneheritöjét lássa”. A falvakban a korábbi években is gyakori volt, hogy a szegényebb szülők nagyobb gyermekei kimaradtak az iskolából a mezőgazdasági munkák idejére. Emellett az indokolás rámutatott arra, hogy nemcsak a kisgazdák, törpebirtokosok, napszámosok és cselédek gyermekeinek segítségére volt szükség otthon, hanem ugyanígy érintettek voltak a falusi kisiparosok, bányászok, gyári munkások családjai is. Ezzel szemben a városi iskolák tekintetében, ahol a gazdasági körülmények nem indokolták a rövidebb időtartamot, a tíz hónapos szorgalmi időt tartotta irányadónak a felső tagozatban, amelytôl azonban indokolt esetben a városi iskolákban is el lehetett térni. Mindezeket számba véve a miniszter kifejezte bizakodását, hogy a szorgalmi idő korlátozása csupán átmeneti lesz és hosszútávon majd bevezethetôvé válik kötelező jelleggel a szeptembertől júniusig tartó szorgalmi idő.

A koncepcióval összhangban az 1940. évi XX. törvénycikk 1. \$ (1) bekezdése rögzítette a népiskola feladatát és a szülők kötelességét ezzel összefüggésben: „A népiskola feladata, hogy a gyermeket vallásos és erkölcsös állampolgárrá nevelje, illetöleg a nemzeti müvelódés szellemének megfeleló általános és gyakorlati irányú alapmüveltségher juttassa és ezáltal az életben való helytállásra és további tanulmányokra is képessé tegye. Ezért minden gyermek gondviselöjének (atyjának, gyámjának, gazdájának) gondoskodnia kell arról, hogy a gondviselése alatt álló gyermek népiskolai oktatásban és nevelésben részesüijön”. Ugyanezen szakasz (2) bekezdése a szülők iskolaválasztáshoz való jogát a korábbi, az iskoláztatási kötelezettség teljesítésének biztosításáról szóló 1921. évi XXX. törvénycikkhez hasonlóan ${ }^{8}$ biztosította: „A gondviselönek jogában van a gyermeket akár lakóbelyén, akár más községben lévö és bármilyen jellegü nyilvános népiskolába beiratni és járatni”. Egyúttal az 1921. évi XXX. törvénycikket, valamint népiskolai közoktatás tárgyában megalkotott 1868. évi XXXVIII. törvénycikk iskolalátogatásra, tankötelezettségre vonatkozó szakaszait hatályon kívül helyezte. ${ }^{9}$

A szülők tekintetében a törvény részletesen szabályozta a tankötelesség teljesítése elmulasztásának következményeit (13-17. \$S); a szülőkkel szemben alkalmazható szankciókat a gyermek tankötelességének biztosítása érdekében írta elő. Amennyiben a szülő nem gondoskodott gyermeke iskolába való beíratásáról, a polgármester először határidő tűzésével felhívta

\footnotetext{
${ }^{7}$ Indokolás „az iskolázási kötelezettségről és a nyolcosztályos népiskoláról” szóló törvényjavaslathoz 394-403.

8 Az iskoláztatási kötelezettség teljesítésének biztosításáról szóló 1921. évi XXX. törvénycikkhez bővebben lásd: NiKLAI, Szülök jogai és kötelességei 51-65.

9 1940. évi XX. törvénycikk 1. S (1)-(2)
} 
kötelezettségének teljesítésére, valamint a mulasztás igazolására, majd ennek sikertelensége esetén a helyi népiskolai hatóság hivatalból beíratta a gyermeket az iskolába, a szülőnek pedig kihágás miatt pénzbírságot kellett fizetnie. Az igazolatlanul mulasztó gyermekekről a helyi népiskolai hatóság a szorgalmi idő első két hónapjában hetente, ezt követően kéthetente köteles volt kimutatást készíteni. A kimutatás alapján felhívták a kimaradó gyermekek szüleit arra, hogy gondoskodjanak az iskola megfelelő látogatásáról. A felhívást követő ismételt mulasztás esetén a polgármester mint községi elöljáróság pénzbírságot szabhatott ki a mulasztott napok és a szülők anyagi helyzetének figyelembe vételével. Ezt követően a gondviselőt kihágás miatt vonták felelősségre és újabb pénzbírságot szabtak ki, ha a felhívás és az első pénzbírság ellenére gyermeke négy alkalommal bekerült az igazolatlanul mulasztók kimutatásába. ${ }^{10} \mathrm{~A}$ szülők felelőssége volt tehát, hogy tanköteles gyermekük iskoláztatásáról gondoskodjanak, amelynek elmulasztását egymásra épülő szankciók alkalmazásával igyekeztek biztosítani.

A korábban is hangsúlyozott elveket ismerhetjük fel a szorgalmi idő, illetve a fokozatos bevezetés vonatkozásában. A szorgalmi időt külön határozta meg a törvény az alsó és a felső tagozat vonatkozásában: „A népiskola alsó tagozatában a szorgalmi idō szeptember hó elejétól június hó végéig tart. Ez̨t a szorgalmi idöt megröviditeni nem lehet. A népiskola felsö tagozatában, valamint a mezógazdasági népiskola elsô és második évfolyamában a szorgalmi idō legalább hat hónapig - rendszerint október hó 15. napjától április bó 15. napjáig - tart”. ${ }^{11}$ Ahogyan az indokolásban láthattuk, a szorgalmi idő tekintetében eltérést engedtek a nagyobb (felső tagozatos) gyermekek körében, így számukra szorgalmi idő indokolt esetben - ide tartozik a családi munkákban való segédkezés - hat hónapra csökkent. Ezzel ellentétben az alsó tagozatos diákok számára külön hangsúlyozták, hogy a törvényben előírt szorgalmi idő rövidebb nem lehet. A hatékony megvalósítás érdekében a törvény 12. \-a a vallásés közoktatásügyi miniszter hatáskörébe utalta, hogy a fokozatosság jegyében megállapítsa, hogy „az iskolafenntartók népiskoláikat mily sorrendben és idöben kötelesek e törvény rendelkezéseinek megfelelöen átszervez̧ni”. ${ }^{12}$ A törvény miniszteri indokolásából egyértelmúen kiderül, hogy a rendszert nem egy lépésben kívánták megvalósítani, hanem hosszú, több éves előkészítés előzte meg. A Vallás- és Közoktatásügyi Minisztérium már az 1920-as években megkezdte a felsőbb osztályok szervezését, majd 1937-ben kiadta a hetedik és nyolcadik osztályokra vonatkozó ideiglenes tantervet is ${ }^{13}$ végül szükségessé vált a kérdés törvényi rendezése, amely az iskolai kötelezettségrôl és a nyolcosztályos népiskoláról szóló 1940. évi XX. törvénycikk megalkotásához vezetett.

A rendelkezések és a nyolcosztályos oktatás bevezetésének fogadtatása eltérő volt a pedagógiai sajtóban. A Néptanítók Lapja úgy értékelte, mint amely intézkedést „nemcsak a pedagógus rend, hanem az egész. magyar társadalom a legnagyobb megértéssel, hálával és szeretettel fogad”"14 - tekintettel arra, hogy a Néptanítók Lapját a Vallás- és Közoktatásügyi Minisztérium adta ki és szerkesztette benne az írásokat, ezt értékelhetjük akként is, hogy a minisztérium büszke volt alkotására, igyekezett annak támogatottságát biztosítani. E lap mellett azonban mások is értékelték a nyolcosztályos rendszer előnyeit. Az Evangélikus Népiskola több lapszámában is foglalkoztak a kérdéssel. A folyóirat 1940 januári számában Buti Sándor, vásárosfalui tanító „A falu és a nyolcosztályos népiskola” címú írásában ismertette, hogy Hóman Bálint költségvetési beszéde alapján az 1940-41-es tanévben már a népiskolák 60 \%-ában (kb. 3600 iskola) megkezdődik majd a nyolcosztályos oktatás. Buti a

\footnotetext{
10 1940. évi XX. törvénycikk 13-17. SS

11 1940. évi XX. törvénycikk 7. S (1)-(2)

12 1940. évi XX. törvénycikk 12. S

13 Indokolás ,,az iskolázási kötelezettségről és a nyolcosztályos népiskoláról” szóló törvényjavaslathoz 394-403.

${ }^{14}$ Hóman Bálint kultuszminiszter költségvetési beszédében bejelentette a nyolcosztályos népiskola megvalósítását 913.
} 
nyolcosztályos tanrend bevezetésének hatásait a magyar falvak tekintetében vizsgálta, méltatva azt az elképzelést, hogy a szegényebb szülők részére lehetôvé teszik a felső tagozatos gyermekek munkába való bevonását, illetve azt, hogy ezáltal nem szükséges tanterem és tanerőtöbblet. Kritikaként azonban felvetette, hogy a felső négy osztály tanulói a féléves szünetek alatt el fogják felejteni, amit megtanultak, valamint visszalépés lesz az ötödik és hatodik osztályosok számára is, akik az eddigi kilenc helyett immár hat hónapig fognak csak iskolába járni, ezért javasolta annak megfontolását, hogy csak a hetedik és nyolcadik osztályosok járjanak félévig. ${ }^{15}$ Az Evangélikus Népiskola 1939 januári számában szívhez szóló értekezést írt Pilisi Pál tanító a „Család és az iskola” címmel. Úgy vélte, a gyermekek nevelése, tanítása szempontjából nagy hatása van a családi életnek, és annak, hogy összhang legyen az iskola és a szülők között. Kiemelte, hogy az otthon látott példa milyen fontossággal bír az érzelmi, erkölcsi fejlődésben lévő gyermekek számára: a szülők egyetértése a nevelés terén, a meghitt és szeretetteljes családi légkör, a becsületes munka mind befolyásolják a gyermek viselkedését. Hozzátette, hogy természetesen rendes, becsületes, dolgozó szülők gyermeke is kerülhet rossz társaságba, amely „el is ronthatja a gyereket”. Úgy vélte azonban, hogy a szülői törôdés ennek megfelelő gátja lehet, ezzel szemben, ha a szülők nem fordítanak kellő figyelmet gyermekükre, könnyen „iskolába nem járó, mulasztó” lehet belőle. Mindezek érdekében rendkívüli fontosságot tulajdonított a tanító és a szülők közötti jó kapcsolat kialakításának és ápolásának, a kölcsönös bizalom megteremtésének, amelyre a tanítóknak véleménye szerint kötelessége törekedni a gyermekek érdekében. ${ }^{16}$

\section{A pécsi tankötelesek tolvajbandája}

Pilisi Sándor tanító fent ismertetett írásában rávilágított a szülői nevelés, illetve annak nem megfelelő volta vagy hiánya hatására, ehhez kapcsolódik a pécsi tolvajbanda esete. A pécsi állami népiskolai Gondnokságtól 1938. június 28-án levél érkezett a tanfelügyelőhöz a „pécsi tankötelesek tolvajbandája” tárgy alatt. Ebben a jelentésében beszámolt a Gondnokság egy tanköteles gyermekekból álló társaságról, amelyet a tárgyban jelzettek szerint tolvajbandaként címkéztek fel. ${ }^{17} \mathrm{Az}$ ügy - tekintettel az eset körülményeire, így például a tolvajbanda tagjainak életkorára - nagy érdeklődést váltott ki a város lakossága részérôl. Ezt jól mutatja az is, hogy a Dunántúl és a Pécsi Napló napilapokban is több cikk jelent meg már a Gondnokság jelentését megelőzően. A Dunántúl 1938. április 21-i és 22-i számában is foglalkoztak a tanköteles gyermekből álló társasággal: az írásokból kiderül, hogy a kilenctagú gyermek-tolvajbanda városszerte betöréseket, lopásokat hajtott végre, két hét leforgása alatt közel ötven ilyen esetről számoltak be. A banda tagjai közül kettő éppen elmúlt 12, hét pedig mindössze 8 éves volt a cselekmények elkövetésekor, ${ }^{18}$ tehát bőven tanköteles korúak voltak. A Pécsi Napló beszámolt az eset érdekességeként arról, hogy a titokzatos tolvajok főként élelmiszereket vittek el, valamint - ahogyan az már másnapra kiderült - azt a kevés pénzt, amit szintén magukhoz vettek, mind cukorkára költötték; így természetesen a rendőség nyomozása

\footnotetext{
15 BUTI, A falu és a nyolcosztályos népiskola 13-18.

16 PILISI, Család és az iskola 16-20.

${ }^{17}$ MNL BaML VI. 502. Bvm. és Pécs v. Tanfelügyelőségének iratai 1087/1938.

${ }^{18}$ Gyermekekből álló tolvajbandát leplezett le a pécsi rendőrség 3.; Mi történjék a leleplezett gyermektolvajbanda tagjaival? 5.
} 
hamar eredményre vezethetett. ${ }^{19}$ A Pécsi Napló április 22-i számában a lopások és betörések számát már hatvanra tették. ${ }^{20}$

A Dunántúl írásában a következőképpen jellemzik a történteket: „Valamennyien iskolakötelesek még, de kello" sqülöi felügyelet és talán nemtörödömség követkęztében a qüllés útjára sodródtak és bandát alakitva követtek el bünöket”'1. A Gondnokság ezt kiegészítette azzal, hogy a gyermekek „a város

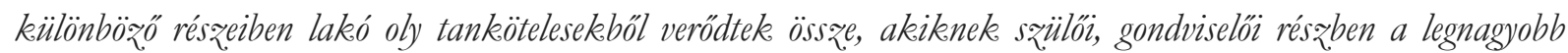
nélkülözések között élnek, részben sok gyermekes családból valók, ahol a sæülök mindegyike kénytelen nap-nap után munkába járni és gyermekeiket felügyelet nélkül bagyni, sajnos olyanok is vannak köztü̈k, akiknek gondviselöi önmaguk sem tartják tiszteletben a magántulajdont és igy természetes, hogy gyermeküke is a lejtöre sodródott”. ${ }^{22}$ Ebből a jelentésből is kitűnik a szülői gondozás fontossága a tanköteles korban lévő gyermekek tekintetében, akik megfelelő felügyelet nélkül a városban szabadon követhettek el büntetendő cselekményeket. Azonban meglepő a szülők reakciója arra, hogy a rendőrség leleplezte gyermekeiket: a Dunántúl arról számolt be, hogy maguk a szülők kérték gyermekük javítóintézetben való elhelyezését, arra hivatkozva, hogy „biábavaló minden szülöi figyelmeztetésük és sæigoruk, ôk maguk munkába járnakés nincs aki gyermekeikere felügyeljen". ${ }^{23}$ Ez azonban amellett, hogy a szülőkre sem vetett jó fényt, a rendőrség számára sem lehetett megoldás, hiszen 12 év alatt a gyermekekkel szemben jóformán semmit nem tehettek, ahogyan erre a Pécsi Naplóban is felhívták a figyelmet: „A rendốrség ezúton is figyelmez̧teti a nagyközönnéget, hogy különösen a kolduló kisgyerekekekel szemben tanúsitsa a legnagyobb óvatosságot, hisz̨en a 12 évnél fiatalabbak. büntetójogilag nem is vonbatók felelósségre, viszont a kárösszeg megtéritését se tudja bižtositani a rendốrség, biszen — amint a példa mutatja - a kis tolvajok sürgösen cukorra, mozira vagy színháajjegyre cserélik be a lopott pénzęeet”. ${ }^{24}$ A Dunántúl másnapi száma már arról számolt be, hogy „a bün lejtójére került gyermekeket dorgálás után hazabocsátva átadták a szülleiknek”. Annak érdekében, hogy a gyermekek züllésének gátat vessenek, már a cikkben felmerült a napközi otthonok létesítése, ahol biztosított az otthoni felügyeletet nélkülöző gyermekek magatartásának figyelemmel kísérése. ${ }^{25}$ A gondnokság ennek megfelelően felmérést végzett - a tolvajbanda ürügyén - a megfelelő szülói gondozást nélkülöző gyermekekrool. Ez alapján megállapították, hogy 335 fiú és 296 lány (iskolák szerinti bontásban a 2. képen) nélkülözi a pécsi tankötelesek közül a megfelelő otthoni felügyeletet, azonban hozzátették, hogy alaposabb vizsgálat után ez a szám valószínúleg még magasabb lenne. A problémát már a tolvajbanda létrejötte elôtt felismerték, és a tendencia javitása érdekében napközit állítottak fel a Szieberth Róbert Elemi Iskolában, azonban helyszűke miatt ez nem volt képes befogadni az összes délutáni gondozásra szoruló tanköteles gyermeket.

A város polgármestere tárgyalásokat kezdeményezett újabb napközik felállítására. Ennek eredményeképpen az ún. Stockház épületét napközi létestésére átengedték, ahol a várakozások szerint 200 tanköteles gyermeknek terveztek napközbeni ellátást adni, azonban további megoldást a Gondnokság jelentése idején (1938 június) még nem találtak. A Stockház a város nyugati felében található iskolák diákjai számára volt elegendő, ezen felül javaslatként a Gondnokság részéről felmerült az állami támogatás igénylése a keleti városrész iskolakötelesei számára felállítandó napközihez. ${ }^{26}$ A Dunántúl már a tolvajbanda tagjainak hazaengedése másnapján megírta, hogy a

\footnotetext{
19 Ötven lopást követett el egy fiatalkoruakból álló tolvajbanda 5.

${ }^{20}$ Hatvan lopást ismert be a tolvajbanda, melynek tagjai 7-14-éves gyermekekből állottak 4.

${ }^{21}$ Gyermekekből álló tolvajbandát leplezett le a pécsi rendőrség 3.

${ }^{22}$ MNL BaML VI. 502. Bvm. és Pécs v. Tanfelügyelőségének iratai 1087/1938.

${ }^{23}$ Gyermekekből álló tolvajbandát leplezett le a pécsi rendőrség 3.

${ }^{24}$ Hatvan lopást ismert be a tolvajbanda, melynek tagjai 7-14-éves gyermekekből állottak 4.

${ }^{25} \mathrm{Mi}$ történjék a leleplezett gyermektolvajbanda tagjaival? 5 .

${ }^{26}$ MNL BaML VI. 502. Bvm. és Pécs v. Tanfelügyelőségének iratai 1087/1938
} 
gyermekek elzüllésének megelőzése érdekében - mivel többek között a javítóintézet a 12 év alatti gyermekek körében nem lehetséges - átalakítják az egyházi kézben lévő Stockházat napközi otthonná a megfelelő gondozást nélkülöző gyermekek számára. A szigeti egyházközség, a ferences rend és a városvezetés összefogásával megvalósított napköziben a tervek szerint a gyermekek orvosi ellátást és étkezést is igénybe vehetnek majd, amely hozzájárulhat egészséges fizikai fejlődésükhöz - a napközi felügyelő tanítói által elősegítendő lelki-szellemi nevelésük mellett. ${ }^{27}$

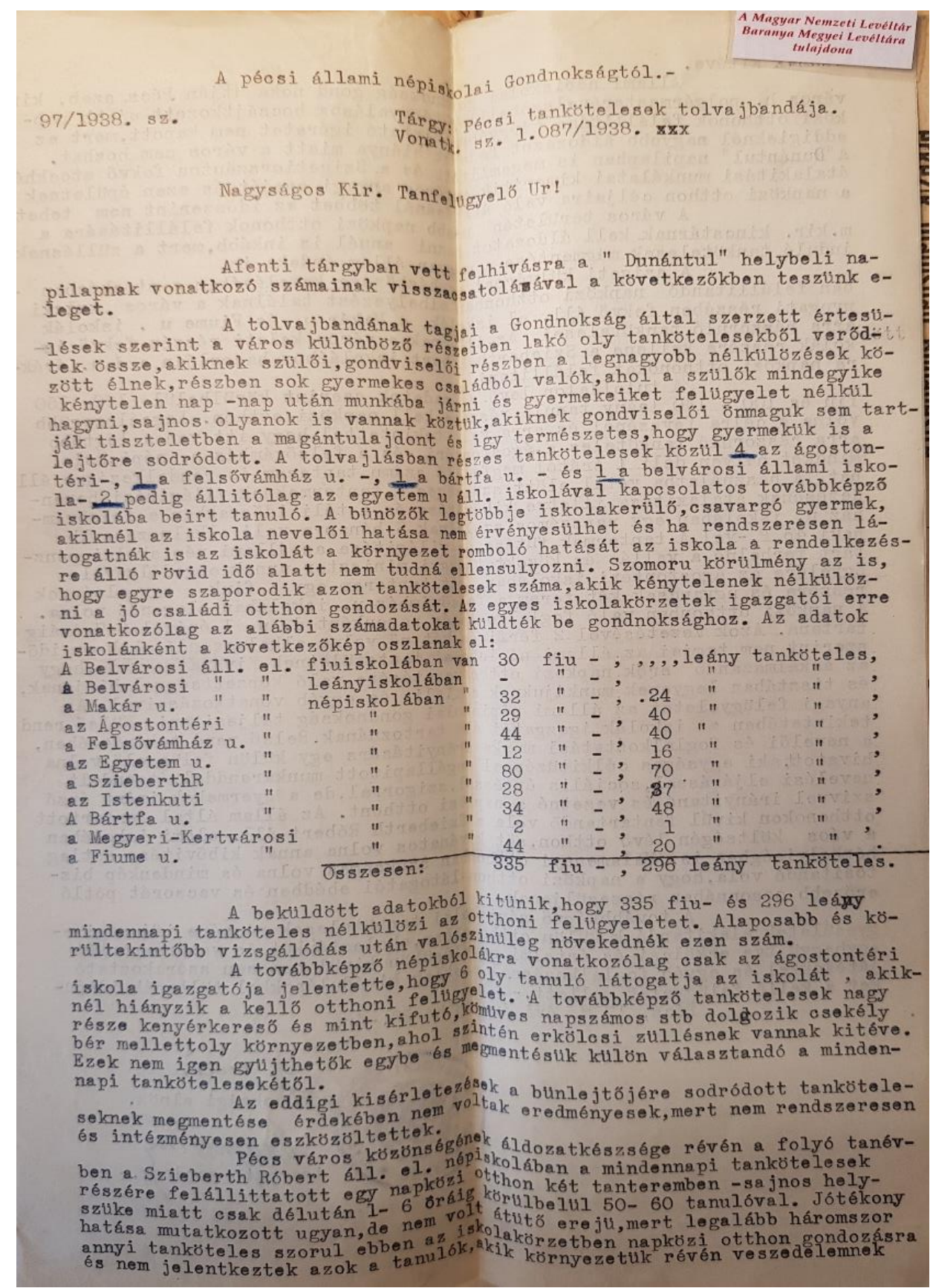

2. kép: A pécsi állami népiskolai Gondnokság jelentése, 1. oldal, MNL BaML VI. 502. Bvm. és Pécs v. Tanfelügyelőségének iratai, 1087/1938

\footnotetext{
${ }^{27}$ Napközi otthon lesz a Szigeti országuti stockházból 2.
} 
vannak kitéve.

A Magyar Nemzeti Levéltár
Baranya Megyei tulajyoi Levéttárar

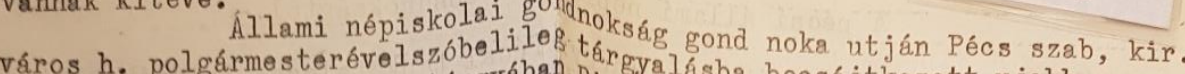
kơzi otthonok felállitása tárgyábar. Biztalásba bocsájtkozott ujabb napigéretet nem kapott,mert $a$. " "Bunántu" napilapban is megemlitett éśnya miatt a város nem hozhat. A "Bunántul" napilapban is megétik a várós a Szigetiorszáuton fekvó stockház átalakitási munkálatai kimerítí átadásán anyagi erojét és ezen épúletnek a napközi otthon céljaira valón ujabbál többet ez időszerint nem tehet. A város teruletén uab napközi otthonok felállitására a m.kir. kincstárnak kell áldozato magyar annál is inkább,mert a zullésnek indul6 tankötelesek megmentése a mar állam érdeke is.

A szigeti kilvárosi egyházközség kezelésében a stocházban -

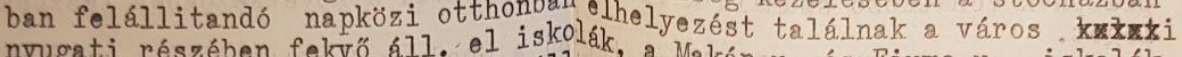
nyugati részében fekvő áll. el iskolák, a Makár u. és Fiume u . iskolák arra rászoruló tankötelesei. Az államnak a város keleti részén fekvo" is kolák részére kellene a Szieberth Robert iskoláéhoz hasonlóan a d.u. órákra napközi otthonokat feléllitani.

A tuloldalon levő számadatok szerint körülbelỉ 100- 150 fiu és 100 - 140 leány tanuló részére kell napközi otthon. Legcélszerïb volna e célra fevésénél és arra való tekintettel, hogy itt van a legtöbb arra rászoruló tanköteles a ágostontéri -és a felsóvámház u. népiskola. Mindkét helyen déli $\mathbb{l}$ órától megfelelő számu tanterem is rendelkezésre állhat. A használatba vétel elött szukséges a tantermeknek világitási berendezésének átalakitása illetve kibővitése és a téli időszakban a felsővámház u. iskolában egy napszámos szolgának 5 hónapra való alkalma zása kb. havi o P.-vel.A tantermek fütése és világitása az állami népiskolai pénztárt terhelné a vallás és közoktatásijgyi miniszter urnak engedélyével. Egyelőre az ágostontéri iskolában két tanterem egy a fiuk, egy aleányok részére és ugyancsak két terem a felsővámház u. iskolában elegendő volna. A napközi otthonban való foglalkoztatás naponként d. u. 1 órától 6-7 óráig tartana. Aźok vezetésével 2 férfi és két nő volna alkalmazandó, akik ez időszerint nem tagjai az állami népiskolai tantetületnẹk. Kịvánatos vola, hogy az alkalmazandó erők napközi otthonvezetésére való képzettséggel birjanak, és tisztában legyenek munkájuknsk sociális és egyéb vonatkozásaival. Az anyagi felïgyeletet az állami népiskolai gondnokság teljesiteni. Külső rend tekintetében az iskolák igazgatói alá tartoznának. Belső rend tekintetében, a nevelői és foglalkoztatási munka irányitásárs egy külön felügyelő volna hivatotṭaki egységes célkitüzéssel megállapitott munkarendàl, átgondolt nevelési eljárással, sociális érzéssel,szigorral, de a gyermekek iránt érző szivvel irányitaná és vezetné a napközi otthont. Az állam által fentartott otthonokon kivịl fentartandó vola a Szieberth Róbert áll. elemi iskolában a váos költségén lévő otthon, sőt kivánatos volna annak kibővitése estleg bérhelyiségben is. Valamennyi otthonban suikséges volna és mindenkép biztositandó vola, hogy a napközi otthon látogatói ebédben és vacsorát pótló erósebb ozsonnában részesilljenek.

A tovåbbképző népisskolai tankötelesek részére if jusági egyesúletek alakitandó $\mathrm{k}$ kiilön otthonokban, aholesténkét és vasárnaponkét egybegyíjtve erkölcsi és értelmi nonokban, ahósikön kivül nemesen szórakoztató játékokkal és egyéb foglalkozással, esetleg kirádulásokkal töltanék ide juket a kellö felugyelet mellett.

$$
\text { Pécs, 7na. évi junius ho 28. -án. }
$$

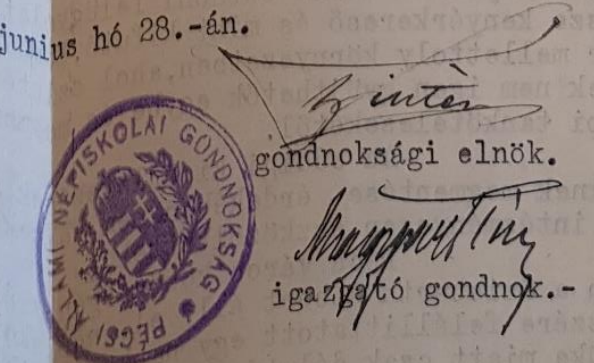

3. kép: A pécsi állami népiskolai Gondnokság jelentése, 2. oldal, MNL BaML VI. 502. Bvm. és Pécs v. Tanfelügyelőségének iratai, 1087/1938 
Felkerestek további helyi egyházközösségeket is újabb napközi otthonok létesítésének támogatására, azonban az evangélikus és a katolikus egyház arról értesítette a tanfelügyelőséget, hogy nem áll módjukban a költségekhez hozzájárulni; ${ }^{28}$ ezzel szemben a református egyházközség úgy nyilatkozott, hogy „kész anyagilag is támogatni olyan napközzi és foglalkoztató otthont, melyet akár a város, akár a társadalom felekeezetteöri jelleggel alakit” ${ }^{29}$ További kutatás tárgya annak kérdése, hogy a napközi otthonok létesítése hogyan alakult egyházi vagy állami támogatással, illetve milyen hatásuk volt a szülői felügyeleti jogok érvényesítésére és annak irányára.

\section{4. Összegzés}

Bár Hóman Bálint kultuszminiszter a törvény miniszteri indokolásában kifejtette, hogy az 1940. évi XX. törvénycikket megelőzően ,igen sok iskolában a társadalom sürgetésére máris be kellett vezetnünk a nyolcosztályos mindennapi oktatást és nevelést” ${ }^{30}$, azonban a levéltári iratok alapján a gyakorlatban még nem alkalmazták ezeket Pécsett a tolvajbanda létrejötte idején. A nyolcosztályos népiskolai oktatás későbbi, törvény általi bevezetése erre a problémára is részben megoldást nyújthatott, hiszen a nagyobb, 7-8. osztályos korú gyermekeket általa legalább délelőttönként foglalkoztatták. Azon gyermekekkel kapcsolatban, akik a megfelelő otthoni felügyeletet nélkülözni kényszerültek, fontos lépés volt a napközi otthonok felállítása annak érdekében, hogy a gyermekek a délutánt is felügyelet alatt és hasznosan töltsék. A szülői gondozás kérdése azonban továbbra is lényegi pontját képezte a tanköteles gyermekek viselkedésének. Ahogy arra több írásban is felhívták a figyelmet, ebben az életkorban a családi környezet számottevően befolyásolta - illetve befolyásolja ma is - a gyermekek viselkedését, így elsősorban a szülő és a gyermek, másodsorban a család és az iskola viszonyban kellett a megoldást keresni - többek között a nyolcosztályos népiskolai oktatás bevezetésének sikerességéhez is.

\section{Felhasznált források és irodalom}

1940. évi XX. törvénycikk

MNL BaML VI. 502. Bvm. és Pécs v. Tanfelügyelőségének iratai, 1087/1938, 1087/6/1938, 1087/7/1938, 1087/8/1938, 1695/1942

BUTi Sándor: A falu és a nyolcosztályos népiskola. Evangélikus Népiskola 1940/1. sz. 13-18.

Gyermekekből álló tolvajbandát leplezett le a pécsi rendőrség. Dunántúl 1938/88. sz. 3.

Hatvan lopást ismert be a tolvajbanda, melynek tagjai 7-14-éves gyermekekből állottak. Pécsi Napló 1938/89. sz. 4.

Hóman Bálint kultuszminiszter költségvetési beszédében bejelentette a nyolcosztályos népiskola megvalósítását. Néptanítók Lapja 1939/23. sz. 913.

Indokolás „az iskolázási kötelezettségről és a nyolcosztályos népiskoláról” szóló törvényjavaslathoz. Néptanítók Lapja 1940/10. sz. 394-403.

KÓSA Kálmán: A nyolcosztályos népiskola és az egyházak. Néptanítók Lapja 1939/20. sz. 793-796.

MANN Miklós: Oktatáspolitikusok és koncepciók a két világháború között. Budapest 1997

Mi történjék a leleplezett gyermektolvajbanda tagjaival? Dunántúl 1938/89. sz. 5.

Napközi otthon lesz a Szigeti országuúti stockházból. Dunántúl 1938/91. sz. 2.

NikLAi Patrícia Dominika: Szülők jogai és kötelességei az iskolalátogatással kapcsolatban a 20. század kezdetén. Díké 2018/2. 51-65.

Ötven lopást követett el egy fiatalkoruakból álló tolvajbanda. Pécsi Napló 1938/88. sz. 5.

PILISI Pál: Család és az iskola. Evangélikus Népiskola 1939/1. sz. 16-20.

${ }^{28}$ MNL BaML VI. 502. Bvm. és Pécs v. Tanfelügyelőségének iratai 1087/8/1938, 1087/7/1938

${ }^{29}$ MNL BaML VI. 502. Bvm. és Pécs v. Tanfelügyelőségének iratai 1087/6/1938

${ }^{30}$ Indokolás „az iskolázási kötelezettségről és a nyolcosztályos népiskoláról” szóló törvényjavaslathoz $394-403$. 